\title{
THE IRRESISTIBLE ForCE OF SELF-DETERMINATION MEETS THE IMPREGNABLE FORTRESS OF TERRITORIAL INTEGRITY: A CAUTIONARY FAIRY TALE ABOUT Clashes IN KOSOVO AND ELSEWHERE ${ }^{1}$
}

Paul C. Szasz

Once upon a time, in a faraway world in which international law still mattered-remember this is just a fairy tale and that I am speaking of a very distant world-there was:

1. A force that many considered irresistible, called SelfDetermination; and there was

2. A fortress that was advertised as impregnable, called the Territorial Integrity of States;

- Adjunct Professor at the New York School of Law. From September 1992 to December 1995 he served as Legal Advisor to the International Conference on the former Yugoslavia. From 1958 he worked in the legal offices of the International Atomic Energy Agency in Vienna, the World Bank in Washington, and the United Nations in New York, retiring in 1989 as Deputy to the U.N. Legal Counsel; subsequently he served as Legal Advisor to the U.N.'s Mission in Namibia (UNTAG) and as a consultant to various U.N. offices. He received his B.S.Eng.Phys. and LL.B. from Cornell University in 1952 and 1956, respectively.

1 This talk was based on a presentation on "The Break-up of States as a Result of Violent Ethnic Strife" in Panel LP-10 on Violence and Culture: Terrorism and International Responses on March 27, 1999, during the 93rd Annual Meeting of the American Society of International Law; it will be very briefly summarized in 93 AM. SOC'Y INT'L L. PROC. (1999). It was again delivered, in substantially the same form as here reproduced, at the annual banquet of the Georgia Society and Georgia Journal of International \& Comparative Law, on April 8, 1999, and to the International Lawyer's Club of Geneva, on May 19, 1999. 
and these two fought many a brave battle for predominance; also participating in this conflict was:

3. A mischievous troll called the Uti Possidetis Principle-whose full name: "uti possidetis, ita possidetis," roughly translates as "[you may] keep what you had"2 - who sometimes reinforced Self-Determination by helping to put firm boundaries around newly created countries which could then claim Territorial Integrity, and sometimes reinforced the Territorial Integrity of States by hardening boundaries against the claims of Self-Determination; further there was

4. An evil wizard called Violence who was trying to attain international status and meanwhile sowed confusion among the other actors. When provoked he could become a giant whom no one could withstand; when allied with Self-Determination he was often called Terrorism, and when allied with the Territorial Integrity of States he was sometimes called State-Terrorism; and, finally, as in any good fairy tale, there was

5. A white knight called International Law, who fought the wizard Violence, sometimes successfully, though rarely so when the wizard turned into a giant.

The present tale is about the interaction of all these actors and about their shifting alliances and conflicts in that faraway world. Each of them has a lengthy but somewhat checkered history:

Violence is the oldest, originating in the Ur-chaos before law emerged.

The Territorial Integrity of States is probably next in seniority, deriving from strivings for stability. It is recognized in UN Charter article 2(4), which upholds the Territorial Integrity of States against external military attacks, but not necessarily against subversion by Self-Determination.

2 See Rein Müllerson, Law and Politics in Succession of States: International Law on Succession of States, part III, Succession to Borders and the Uti Possidetis Principle, in Dissolution, CONTINUATION AND SUCCESSION IN EASTERn EUROPE 19-21 (Brigitte Stem ed., 1998). 
International Law was born some 350 years ago in Westphalia at the end of the Thirty Years War. Since then it has developed greatly and especially in the past half century has enjoyed a healthy adolescent growth spurt.

Self-Determination ${ }^{3}$ itself entered the stage at the end of the 18 th century with the American and French Revolutions, one against external oppression and the other against internal. The Vienna Conference ending the Napoleonic wars sought to contain it, but in the 19th century it nevertheless manifested itself in the Balkans with the liberation of Greece, Serbia and Montenegro from the faltering Ottoman Empire, and in the decolonization of Latin America. During World War I both Lenin and Wilson proclaimed it-from different perspectives ${ }^{4}$ - but at the Paris Peace Conference it received only lip service as the Allied and Associated Powers re-arranged the map of Central Europe and the Balkans to suit their own mis-perceived interests. After World War II, Self-Determination was proclaimed in Articles 1(2) and 55 of the UN Charter-though not in the Chapters relating to non-self-governing or trust territories. Nevertheless, it became the intellectual engine of decolonization, a process now essentially completed. Most recently Self-Determination received a new lease on life-though subject to some constraints that I will mention-with the break-up of some of the post-WWI constructs: Czechoslovakia and the Soviet Union peacefully, and Yugoslavia violently.

Finally, the Uti Possidetis Principle apparently came into being with the decolonization of Latin America and later was observed in that of Africa. More recently it was cited as an apparent stand-in for the Territorial Integrity of States-as a justification for not allowing Croatia and Bosnia to be divided along ethnic lines, after these two new states had themselves been allowed to split off from Yugoslavia. ${ }^{5}$

So, who is stronger: Self-Determination or the Territorial Integrity of States? And on whose side is International Law? In the past half century their battle has been carried out both in abstract legal instruments and in those relating to specific conflicts:

As already mentioned, both principles are recognized in the UN Charter, but quite non-confrontationally.

3 The literature on Self-Determination is enormous. Some recent books include: MODERN LAW of SElf-Determination (Christian Tomuschat ed.); ANTONIO CasSESE, SelfDetermination of Peoples: A legal Reappraisal (1995); Thomas D. Musgrave, SelfDETERMINATION AND NATIONAL MINORITIES (1997).

4 See CASSESE, supra note 4, at 14-23.

5 See Opinion No. 2, dated Jan. 11, 1992, of the Arbitration Commission of the EC Conference on Yugoslavia (the "Badinter Commission"), reprinted in 31 I.L.M., 1488, 1497-99 (1992). 
The two 1966 Human Rights Covenants refer only to Self-Determination; ${ }^{6}$ they were adopted at the height of decolonization and these references helped to reinforce that process. But decolonization raised few if any issues of the Territorial Integrity of States, because most colonies were far from their metropolitan countries. The claims of France that Algeria, and of Portugal that Angola and Mozambique, were integral parts of their territories, were in effect laughed out of court.

Interestingly enough, the famous Decolonization Resolution of the UN General Assembly ${ }^{7}$ was a harbinger of the future: after boldly proclaiming in paragraph 2 that "[a]ll peoples have the right to self-determination," it cautioned in paragraph 6 that "[a]ny attempt aimed at the ... disruption of the national unity and the territorial integrity of a country is incompatible with the purposes and principles of the Charter of the United Nations." Maybe a close call, but that important round appears to have gone to Territorial Integrity.

Recently, however, the conflict has become more one-sided. The August 1992 London Conference-which also established the International Conference on the Former Yugoslavia - in its "Statement of Principles," after fleetingly mentioning "the promotion of tolerance and the right to self determination," speaks strongly of "the fundamental obligation to respect the independence, sovereignty and territorial integrity of all states in the region; and to respect the inviolability of all frontiers ... Rejection of all efforts to . . change borders by force." 8 Thus the Conference was launched, largely to resolve the Bosnian conflict, with its feet hobbled by the absolute requirement to preserve the Territorial Integrity of Bosnia-Herzegovina.

The July 1998 Rome Statute of the International Criminal Court, in concluding its definition of "War Crimes," affirms that "[n]othing [in the part of the definition dealing with civil wars] shall affect the responsibility of a Government ... to defend the unity and territorial integrity of the State ...."9

6 See International Covenant on Civil and Political Rights, Dec. 16, 1966, 999 U.N.T.S. 171, art. I.1; International Covenant on Economic, Social and Cultural Rights, Dec. 16, 1966, 993 U.N.T.S. 3, art. I.1. Both state: "All peoples have the right of self-determination. By virtue of that right they freely determine their political status and freely pursue their economic, social and cultural development." This provision was included in the Covenants by specific direction of the General Assembly in A/RES/545 (VI) of Feb. 5, 1952.

7 A/RES/1514 of Dec. 14, 1960.

8 See The London Conference Document LC/C2 (FINAL) of Aug. 26, 1992, ๆข v, viii, reprinted in 31 I.L.M. 1488, 1533-34 (1992).

$\rightarrow$ Rome Statute of the International Criminal Court, U.N. Diplomatic Conference of Plenipotentiaries on the Establishment of an International Criminal Court, at art. 8(3), U.N. Doc. A/CONF. 183/9 (1998), reproduced in 37 I.L.M. 1002 (1998) and, in a corrected version, in U.N. Doc. PCNICC/1999/INF/3. 
Just a year ago, last December, the General Assembly adopted a resolution on "Maintenance of international security-prevention of the violent disintegration of States," in which Self-Determination is no longer even mentioned. $^{10}$

The situation in Kosovo is most illustrative. After months of Serb atrocities against the Albanian Kosovars," culminating in the current campaign to expel all of them from the province, the NATO allies are still defining the goal of their massive bombing as just the restoration of the pre1989 autonomy of Kosovo within Serbia, and resisting - albeit now somewhat less forcefully - the call for complete independence. ${ }^{12}$

It is not difficult to see why that should be so. International Law is largely made and practiced by states, that is by governments, and each government is bent on at least protecting its own Territorial Integrity. And here it should be recognized that many states have either ethnic or other faultlines that make them vulnerable to the threat of Self-Determination. Just think of Canada and Quebec; of Spain and the Basques and the Andelusians; France and Corsica; Great Britain and Northern Ireland, Scotland and Wales; Belgium divided between the Walloons and the Flamands; Sri Lanka and its Tamils; Nigeria and the Ibos; Russia with Chechna and a score of other restless peoples and provinces; not to speak of the Kurds and their several unhappy hosts.

10 A/RES/53/71 of Dec. $4,1998$.

"Soon after the conflict took a bloody tum the Security Council adopted resolution 1160 of Mar. 31, 1998, paragraph 5 of which starts: "The Security Council, . . Agrees, without prejudging the outcome of the dialogue, with the proposal in the Contact Group statements of 9 and 25 March 1998 [S/1998/223 and /272] that the principles for the solution of the Kosovo problem should be based on the territorial integrity of the Federal Republic of Yugoslavia ..."

12 The remarks reproduced in the text were of course made early in the NATO bombing campaign. About a month later, on May 8, the G-8 Foreign Ministers (the G-7 plus Russia) agreed on a Statement, which inter alia called for "[a] political process towards the establishment of an interim political framework agreement providing for a substantial self-government for Kosovo, taking full account of the Rambouillet accords and the principles of sovereignty and territorial integrity of the Federal Republic of Yugoslavia and the other countries of the region ...." This statement is reproduced in annex 1 to S/RES/1244 of June 10,1999 . When a month later Milosevic had been persuaded to accept the terms set out in the G-8 Statement, the Security Council adopted the above-cited resolution, to which it annexed the Statement, and which inter alia reaffirmed "the commitment of all Member States to the sovereignty and territorial integrity of the Federal Republic of Yugoslavia and the other States of the region, as set out in the Helsinki Final Act and annex 2," id. at 2, and authorized the UN Secretary-General "to establish an international civil presence in Kosovo in order to provide an interim administration for Kosovo under which the people of Kosovo can enjoy substantial autonomy within the Federal Republic of Yugoslavia." Id. at annex 2. 
So, when the Territorial Integrity of a State is threatened anywhere in the world, other countries instinctively come to its defense. This is what has happened in respect of Cyprus, which has been effectively divided between a Northern (Turkish) sector and a Southern (Greek) one since 1974, when both sectors were ethnically cleansed; it is clear that the twenty percent Turks will not live in a state with a massive Greek majority, but nevertheless the international community is insisting there can be only one Cyprus-even if the United Nations must patrol the boundary between the two sectors indefinitely. ${ }^{13}$ As already recalled, at the 1992 London Conference it was decided that Bosnia must remain a single state, even though about half the population, that is the Serbs and the Croats, did not want to live in a single state either with each other or with the Muslims; now the Dayton "peace" is secured by a substantial NATO force, which on the one hand is quite unable to accomplish the return of refugees and on the other will have to stay indefinitely lest the civil war resume promptly-all this to preserve a purely pro forma Territorial Integrity. And now, in Kosovo, the world community is again insisting that after all that has happened that province must remain part of Federal Republic of Yugoslavia, even at the cost of a massive, long-term NATO occupation. When will we ever learn?

The trouble is, that all these solutions underestimate the wizard Violence, hoping against hope that he (or should it be she) can either be soothed or scared off by stern posturing. There are of course situations when Violence, in the form of Terrorism, can be contained without requiring the government seeking to preserve Territorial Integrity to resort to an unacceptable level of State Terrorism. Think of the British and Northern Ireland-though there it was touch and go; similarly in Spain with the Basques. In respect of Chechna, on the other hand, Violence in effect won; the solution has been de facto independence and thus a breach of Territorial Integrity in favor of SelfDetermination $^{14}$, though the de jure situation remains unchanged.

Let me now advance a proposition-which may be unpopular because it appears to legitimize Violence, or rather it openly assigns it a rôle in determining the conflict between Self-Determination and Territorial Integrity.

${ }^{13}$ This is the task of the United Nations Peace-keeping Force in Cyprus (UNFICYP), established in 1964. The Force is described in chapter 9 of THE BLUE HELMETS: A REVIEW OF UNITED NATIONS PEACE-KEEPING (3rd ed. 1996).

${ }_{14}$ As of the final editing of this essay (end-December 1999), Russia is engaged in a full assault on Chechna, which may well succeed in restoring the province to central control. Although ostensibly taken in response to continuing Terrorism within or originating in Chechna, the military violence is such that it has been widely criticized as constituting, in effect, StateTerrorism, which may in turn reduce the legitimacy of Russia's occupation. 
My proposition is that when Terrorism becomes so strong that it can no longer be suppressed without an unacceptable level of State-Terrorism, then the state concerned has, either as a victim of Violence or as its perpetrator, lost the legitimacy that enables it to insist on its Territorial Integrity. Sometimes a State can avoid that fate by countering Terrorism not only by its own Violence, but also by other measures that deprive the terrorists of support and ultimately of legitimacy. In other words, Violence must be given its due, either by skillfully turning it aside or by formally yielding to it; it cannot just be disregarded because it is, almost by definition, not legitimate.

Let us now look at some alternative courses of action for the international community in situations where ethnic or other conflicts lead to Violence within a state:

1. The international community can refuse to intervene, even if a country is unable to control domestic Violence; if horrible massacres result, just shut off $\mathrm{CNN}$, and close borders to the entry of refugees. But, in practice, these measures cannot be taken, as we learned in Rwanda and now again in Kosovo.

2. The world community can also assist in suppressing Self-Determination in favor of Territorial Integrity-the course it is at present inclined to take. In Bosnia we see the results of that strategy: an indefinite, massive occupation, which still does not succeed in really reunifying the country and cannot help the displaced half of its population to return to their original homes. All of NATO's forces and all of NATO's men really can't put Yugoslavia/Kosovo together again!

3. Finally, the international community can tip the scale in favor of Self-Determination and against unconditional Territorial Integrity; if thereby new states are created it will, at the most, have to patrol their new mutual border - a much easier task than an occupation.

As to the economic viability of such state fragments, this should matter less and less in a more and more integrated region or world.

So, there it is. A pragmatic solution that may not be entirely morally pleasing, because it assigns such an important role to Violence in determining the outcome. And thus we see that this is not really a fairy tale. For in a fairy 
tale evil wizards are always defeated and destroyed, and the principal protagonists live together happily ever after. But the real world is not like that. It is an imperfect world in which unsatisfactory compromises must be made and ideals cannot always be maintained in their pristine purity. Nevertheless, knights must sally forth to right what wrongs they can and to protect the powerless as far as possible. And in doing so, they may find International Law as a useful ally, by no means invincible but hopefully steadily growing stronger.

These thoughts reflect my personal experiences during the past decade: first in participating in the successful liberation and attainment of independence of Namibia; then in a long, fruitless attempt to negotiate a constitution for Bosnia that would square the circle of creating a democratic state which a majority of its citizens do not want; and finally in trying to formulate a new constitution for Cyprus in that the conundrum was essentially the same: how to create a functioning and democratic state, no matter how decentralized, that fully and permanently protects a suspicious minority against a large and unsympathetic majority. In these assignments I have learned both the limitations of international law and the satisfaction of pursuing it. 